


\title{
Background of Achieving a Realistic Legislative Criminal Policy in Iranian \\ Penal Laws
}

\author{
DOI: https://doi.org/10.46398/cuestpol.3969.16
}

\author{
Ahmad Reza Vanaki * \\ Karim Salehi ${ }^{* *}$ \\ Maryam Naghdi Dourabati ***
}

\begin{abstract}
For a criminal policy, in the broadest sense, to be successful and compatible with a realistic view of the criminal phenomenon in the field of pragmatism judgment and to achieve its objectives, it needs a background which, in its absence, not only laws based on realistic criminal policy fail, but their application in such a situation will cause a double damage to society: legal and moral. Apply methods of social prevention in the economic and cultural dimension, observing the principle of minimum criminal law, the mandatory anticipation of the presentation of a personality profile in all crimes committed and finally, the establishment of a care administration to comply with the implementation of realistic laws in the best possible way. It is concluded that this path that combines criminal policy and pragmatic legal realism is one of the desired areas in question in the field of criminal investigation in Iran. This research, which is conducted using the content analysis method, identifies the background for the implementation and enforcement of a realistic legislative criminal policy in Iran to remove obstacles to this advanced scientific knowledge.
\end{abstract}

Keywords: realistic penal policy; crime prevention; personality profile; principle of individualization; principle of minimum criminal law.

* PhD Student, Department of Law, Shahrekord Branch, Islamic Azad University, Shahrekord, Iran. ORCID ID: https://orcid.org/oooo-0oo2-2872-1753. Email: ahmadvanaki@yahoo.com

** Assistant Professor, Department of Law, Shahrekord Branch, Islamic Azad University, Shahrekord, Iran. ORCID ID: https://orcid.org/oooo-0002-5297-4152. Email: dadvarz@gmail.com

*** Assistant Professor, Department of Law, Shahrekord Branch, Islamic Azad University, Shahrekord, Iran. ORCID ID: https://orcid.org/oooo-0002-3673-1863. Email: Naghdi707@gmail.com 


\section{4 \\ Ahmad Reza Vanaki, Karim Salehi y Maryam Naghdi Dourabati \\ Background of Achieving a Realistic Legislative Criminal Policy in Iranian Penal Laws \\ Antecedentes de la consecución de una política penal legislativa realista en las leyes penales iraníes}

\section{Resumen}

Para que una política criminal, en el sentido más amplio, tenga éxito y sea compatible con una visión realista del fenómeno criminal en el ámbito del juicio de pragmatismo y logre sus objetivos, necesita un trasfondo que, en su ausencia, no solo leyes basadas en una política criminal realista fracasan, pero su aplicación en tal situación provocará un doble daño a la sociedad: jurídico y moral. Aplicar métodos de prevención social en la dimensión económica y cultural, observando el principio de ley penal mínima, la preceptiva anticipación de la presentación de un perfil de personalidad en todos los delitos cometidos y finalmente, el establecimiento de una administración de atención para cumplir con la implementación de leyes realistas en la mejor forma posible. Se concluye que este camino que conjuga política criminal y realismo jurídico pragmático es una de las áreas deseadas en cuestión en el ámbito de investigación penal en Irán. En esta investigación, que se realiza mediante el método de análisis de contenido, se identifica los antecedentes para la implementación y aplicación de una política penal legislativa realista en Irán con el fin de eliminar los obstáculos a este conocimiento científico avanzado.

Palabras clave: política penal realista; prevención del delito; perfil de personalidad; principio de individualización; principio de derecho penal mínimo.

\section{Introduction}

There are basically two views on the criminal phenomenon and how to react to it. The first view is the abstract legal view, which is also considered idealism in philosophical discussions. In an idealistic view, crimes are considered in the school of natural law or innate law school. In the school of innate law, on which part of Iran's criminal policy is based, the ideal laws or manifested in the criminal arsenal to build an ideal society. These laws are transcendental and have come to bring happiness and bliss to all human beings. In the abstract legal perspective, preventions appear as criminal and in the form of general and specific prevention, and in some cases have permanent exclusion function through extermination, and in some cases, punishments try to control and prevent delinquency occurrence by disabling criminals.

But in the present article, the criminal phenomenon in realistic criminal policy is examined in terms of the background and requirements for 
achieving results. Criminal policy in the broadest sense includes all the stages affecting the criminal phenomenon from the pre-criminal stages, investigating the causes, and preventing them, whether state-based or social prevention, quality of reactions, type of punishments and security measures required to execute punishment and even pre-execution stages. The matter of fact is that in present-day Iran, we are facing traffic in the cases of the prosecutor's office and criminal courts and unbridled criminal inflations at the social level. Social prevention in the economic-cultural dimensions is not well illustrated and implemented.

In the field of economics, lack of fairy distribution of Labor and wealth has led the society towards an anomic society; and in the fields of culture, lack of growth-oriented and growth-centered programs, in the long run, has left its problems and difficulties. In the fields of legislative criminal policy, the legislature has followed a duel heterogenous policy, so that while in one part of the law it uses an abstract legal perspective and criminal policy in a narrow sense, it has a legislated with a realistic perspective, in another significant part of a criminal policy in the broad sense. But in this area, despite the application of the most advanced paradigms in criminal law in the field of a judicial and executive the criminal policy, it has faced systematic inefficiencies. What is certain is that it is not enough just to legislate and adopt advanced laws of derived from criminal policy data in line with modern science, but the necessary grounds must also be provided.

Applying community-based and status-based prevention, decriminalization, and the judgement as much as possible, establishing an institution for diagnosis in the company of courts, establishing a probation office, employing criminological the judges and specializing in judging, inservice training of former hired judges and such is one of the cases that prepares the ground for the implementation and operation of realistic criminal policy. The question is whether the criminal law, which originated from a realistic criminal policy, has been well received by the judicial authorities. Has realism led to pragmatism, or are we dealing with a series of beautiful laws that are on the on the pages of law booklets? And what item can the pragmatic solution of realistic laws depend on?

In the present article, and attempt will be made to explore Iran's criminal policy in the field of realistic law and pragmatic barriers in order to offer suggestions for merging realism with pragmatism.

\section{Criminal policy and the concept of realism}

In a historical course, criminal policy has started from its narrow concept and meaning and has reached its peak with progress in the broad concept based on realism towards the criminal phenomenon. for the first 


\section{Ahmad Reza Vanaki, Karim Salehi y Maryam Naghdi Dourabati \\ 276 Background of Achieving a Realistic Legislative Criminal Policy in Iranian Penal Laws}

time in 1803, the German professor Feuerbach uses the term criminal policy in his book on criminal law, and this is the first time that the term criminal policy has entered the real of criminal law. According to Feuerbach, criminal policy includes a set of repressive methods through which the government responds to Crime by resorting to them (Travis III, 2011). A narrow interpretation of criminal policy, which is also known as "Criminal policy"; It should be note that the only prevention considered in this definition is criminal prevention, which with its intimidating aspect in general and particular is effective on the offender and the surrounding community (Ristroph, 2020).

In France (in 1905), Mr. Cauchy, in his treatise "The science of a prisons' Administration and laws" distinguishing criminal policy from pure science, which he considered to include criminology, sociology, and criminal anthropology, sought to place criminal policy among other disciplines of criminal science. However, in his opinion, criminal policy means "an applied science whose goal is practical success in the rational effective organization of the fight against crime" (Travis III, 2011: 58).

According to this view of criminal policy and crime, which is a legal concept, deviation (deviance) is also considered a social concept. This viwe does not rely solely on reression and intimidation through punishment, but also includes prevention data, which, of course, includes social prevention in the form of social, cultural, moral systems and so on (Shaygan and Rahmani Klakuob, 2019).

With the above descriptions, it can be said that criminal policy is a science that, based on scientific and philosophical data and approaches, and taking into account historical conditions and facts, seeks appropriate response to the criminal phenomenon through criminal and preventive measures, solving the resulting problems as well as establishing security and normative calm in the criminal atmosphere of society. The occurrence crime and social deviation at all times and places are considered perfectly normal law and following the realities of human societies, which increasingly reflects the need for a realistic reaction to this phenomenon. Undoubtedly, resorting to an idealistic and slogan-based movement in dealing with a criminal phenomenon that has little to do with the facts and the law, is doomed to inefficiency and Failure from the very beginning.

\section{Prevent one dimension of realistic politics with a background function}

I think the highest level of realism in a criminal policy is the extent to which that policy approaches crime prevention, the success of which lies in knowing the members of the target community accurately. As we see 
in criminology, crime is not caused by one cause and the emergence of a criminal phenomenon is the result of the convergence of different factors and the prevalence of underlying conditions.

The occurrence of delinquency can be due to involuntary individual causes with a subset of individuals' physical and intrinsic factors of delinquency, diseases and mental disorders and character and personality disorders. Also, general factors of delinquency include social factors, geographical environment, economy environment and political environment with their broad sub-branches, including the factors of formation and occurrence of criminal phenomenon (Brannigan, 2013).

What is certain is that prevention has always been simpler and less expensive than treatment. Realistic criminal policy in this dimension owes its facilitator approaches to the knowledge of criminology. Although criminal prevention is also white widespread in the types of prevention, as we will see, criminal prevention has not been very successful, and countries with low crime rates have spent most of their budgets on prevention of criminological origins instead of paying and spending in penal institutions. In the following, the realism of criminal policy in this field will be explained by describing the types of prevention methods.

\section{a. Criminal prevention of idealistic institution}

The founders of these theories their schools and followers, who believe in free will and conscious human choice, justify punishment on the basis of social benefit and its deterrent effects (Thorburn, 2011). For example, Jeremy Bentham, who himself is one of the founders of the school of social benefit, says "if you suspend and stop the punishment, then the word will become a sense of crime and social team will disappear" (Canter, 2008: 28). One of the most important features of this type of prevention is that according to this process, any crime committed by any criminal can be prevented in a way, while each crime has its own tools for prevention. Another feature is that in this type of prevention, the focus is on punishment and dealing with the perpetrator and the role of other factors in the emergence and occurrence of crime is ignored (Clarke, 1983). An issue that distances us from realism towards the criminal phenomenon is the abstract legal view of crime and delinquency, which in the present day has lost its justification with the development of science related to criminal law and their impact on criminal policy.

Let us now return to the fact above. Various underlying factors cause that crime or rather criminal phenomenon; Factors that have developed a particular personality over time, which in its dimensions include criminal capacity and dangerous state. 


\section{Background of Achieving a Realistic Legislative Criminal Policy in Iranian Penal Laws \\ b. Prevention of juvenile delinquency and prevention of adult delinquency}

Provision of delinquency, also known as growth-based prevention or early prevention, is done through early psychological-social interventions. The emergence and spread of developmental prevention is often attributed to David Farrington's research (Farrington, 1995). Farrington's starting point is the theory that delinquency is part of the larger syndrome of social behavior that begins in childhood and continues into adulthood. His theory is also based on the premise that the early onset of delinquency, for what Farrington calls "latent criminal potential", indicates subsequent criminal activities. Accordingly, and in the practice of positive criminology, Farrington believes that the roots of the antisocial personality traits found among professional and persistent offender can be the diagnosed and treated in adolescence. In this regard, Farrington defines growth-oriented or early preventions as "interactions designed to prevent the growth of the potential for committing crime in individual" (Crawford and Evans, 2017: 23).

The purpose of this type of prevention is to identify children at risk, deviant or delinquent children, and two intervene in their socialization process through the family institution, teaching social skills to children and adolescents, educating teachers and school officials. It seeks to prepare them for a better life by empowering them. This type of prevention has characteristics that are the most important of being early, multi-basis, and long-term (Vold, 1958). Attempts to connect social contexts and growth are faced with the determination of two types of growth description methods: one is developmental programs that cover the early years of life, and the other is a perspective that covers a long life (Ross and Polk, 2017).

In a macro perspective, the reality of Iranian society today is facing whispered corruption among the affluent ruling classes. Exploration and application of the theory of pressure on society (Darabi, 2018). Although it covers some of the inferior problems, it has not provided a plausible justification for crime of the white collars; people who have economic power, social status, and prosperous life, but do not feel any responsibility towards their compatriots, and despite enjoying all the amenities and power do not turn away from committing macroeconomic crimes. If we take a brief look at the last few decades, the disturbing lack of a growth-oriented program with long-term intergenerational the perspective has left us with many such problems today, problems that the application of Strict repressive laws cannot manage. With the above description, if the community board and special community manager did not formulate and implementing and efficient growth-oriented program, the penal institutions will not succeed in achieving their preventive goals by threatening and intimidating them. 


\section{c. Social crime prevention and realistic criminal policy}

Social crime prevention is the strategy that prioritizes community members' participation in the active prevention of criminal behavior and other social harms and seeks the cause of crime in social structures (Homel et al., 2015). Among the various approaches to crime prevention, the type of social prevention done through the development of social characteristics and all improvement of the welfare and quality of life of people in society, has found a special place among criminological research and realistic criminal policies. The need to study the criminal social conditions, pre-criminal situations, joint efforts of society and its various pillars leads to a broad and guaranteed relationship between the criminal policy of democratic societies and social policies through social measures aimed at socializing individuals, promoting human security and social justice (Darabi, 2018).

Therefore, considering the functional explanation of prevention as an important tool on the path to sustainable development; and considering that in order to deal with the criminals phenomenon must go to the underlying factors and its social origins and through their neutralization, eliminate or at least reduce the possibility of crime; and by understanding the fact that the issue of criminal confrontation may be only transient and responsive in the short-term, but permanently and in the long run perpetrators behavior will change and will emerge in new forms of crime; and that based on scientific facts, relying on punishment and intensifying criminal reactions, without considering the causes and contexts of crime, is considered as a kind of the struggle against the effects and in the word of realism it cannot have a significant impact, and therefore, paying attention to the pre-criminal stages is considered as necessary and inevitable (Garcia-Yi, 2014).

Measures such as holding in formed free elections and democratic government, equitable distribution of wealth in society, eliminating injustice and economic inequality, providing employment opportunities for all those who have the talent and ability to work, providing marriage conditions and facilities for young people, poverty alleviation, developing and strengthening of institutions such as family, school, cooperation and interaction between various social organizations and institutions such as the legislature, the executive and the judiciary in approving and implementing various prevention programs and policies, including social preventive measures (Darabi, 2018).

Let's take a brief look at the criminal phenomenon in Iran. We will easily find the effect of pressure theory data in the economic cultural aspects in a realistic and experience-based way. At present, Iranian society's reality is the lack of fair equal division of labor and wealth and even culture. The bitter truth is that economic factors cover a large part of our crimes, and the other part goes back to the cultural context of issue. 
Ahmad Reza Vanaki, Karim Salehi y Maryam Naghdi Dourabati
280 Background of Achieving a Realistic Legislative Criminal Policy in Iranian Penal Laws

Undoubtedly, the application of social prevention realism will significantly reduce many current crimes and lead to security and sustainable development.

\section{d. Prevention in the face of realistic criminal policy}

According to what was mentioned in the above paragraphs, the main basic element of a realistic criminal policy is its approach to prevent crime and in fact to prevent the formation of a criminal phenomenon in fact, prevention is an effective tool to prevent the occurrence of delinquency, to prevent the persistence in delinquency, as well as the elimination or modification of dangerous criminal situations and is one of the main components of a criminal policy in its broad effective meaning, which of course without considering its, the possibility of actually claiming an effective criminal policy would be nothing more than a false claim. However, realistic criminal policy in general, and significantly based on no-criminal prevention methods, focuses entirely on "multi-institutional or interinstitutional prevention" of crime, the scientific establishment of which, in the group of social context empowers and attracts the involvement of a various institutions, both formal and informal, of the social system, in order to remove the black spot of deviation and delinquency from Society (Warf and Grimes, 1997).

In democratic societies whose criminal policy model is libertarian, democratically based on realism items, structural crime prevention perspectives are predominant. In this regard, criminologists consider crime a product of natural characteristics and inadequacies of the social environment. They believe that the greatest possibility of prevention is to change the perpetrators of crime, potential offenders by eliminating deprivations, and improving their personality and training them. Besides, prohibited behaviors in the form of crime, through determining the enforcement guarantee, which represents the value of it in society, are specified following the principle of legality of crime and punishment, and any reaction such as criminal administrative, disciplinary, and so on is considered as one of the essential prevention tools to prevent any encroachment on the security and peace of the country and its citizens (Darabi, 2018).

What is certain is that prevention in a realistic criminal policy has a criminological, which has no place in the repressive law, since criminal law is based on the principle of legality of crimes and punishments. On the other hand, preventive criminology seeks predictive and active policies before the formation of the criminal phenomenon. As we can see, the occurrence of financial crimes with economic motives in both micro and macro models have their reasons. Undoubtedly, creating economic prosperity, efficient employment and fair distribution of work and wealth in a society will 
significantly reduce the crime rate of financial and financial-related crimes, and in the macro dimension of meritocracy and time in hiring committed compassionate officials who have learned life is skills training in a growthoriented system, will block the way for macroeconomic crimes. Creating an obstacle in the way of committing crimes and the difficulty of achieving results in an anomic society will undoubtedly make the path of delinquency difficult in the condition of criminal situations. What is certain is that in order to achieve the result and effectiveness of the criminal policy, the next step is to recognize the realities of the target community and not neglecting to use all the necessary methods for prevention

\section{Dimensions of criminal realism}

In an abstract legal perspective, a crime is a behavior that the legislature has labelled criminal for its own reasons.

Criminal law in countries is adorned with scientific data under the influence of criminological data and other science related to following a realistic criminal policy. Hence, a delinquent person is an individual with undeniable internal conflict who is influenced by various criminal capacity factors in his/hair personality dimensions. Determining punishments is not a primarily for humiliation, correcting black spots formed in inner personality in order to adapt to the surrounding society so that he will love others like law-abiding citizens and from positive attention to others do not exchange the feeling of being human and the resulting pleasure with any other a stimulus.

Every human being must react to his social environment's stimuli in harmony with the demands of the surrounding environment and the local community. Delinquency is the emergence of human reactions that creates more or less obvious problems for society, and one whose behavior is considered contrary to the interests of the social environment is called a criminal. Hence whenever and internal or external stimulus reaches the brain, there is a slight interruption in its balance. This interruption, in turn causes the emergence of a series of neural currents that vary in the position and structure of the brain. Some of its regulatory mechanisms attempt to direct brain phenomena one after the other, which is eventually restored by a specific final reaction.

In cases where this balance is not established, the final reaction is a new stimulus that in turn causes an imbalance. Therefore, inconsistencies and incompatibilities manifest themselves as a series of chain reactions. So, in compensation, ability is a phenomenon that occurs in the darkness of the relationship between the individual and the psycho-social environment. Of course, the individual's biological personality will affect this process and 
Ahmad Reza Vanaki, Karim Salehi y Maryam Naghdi Dourabati
282 Background of Achieving a Realistic Legislative Criminal Policy in Iranian Penal Laws

the compatible individual will be spiritually approved and supported by his group. However, personal maladaptive behavior in most cases, causes rather hostile reactions from the external environment (Cohen et al., 1989).

In terms of realism, in the criminal phenomenon appears as the behavior of the human individual (human reality) against society (social reality) (Brown, 2004). From a real point of view, a criminal phenomenon is a disturbance in the social order (social reality) due to the behavior of a human individual who is the member of that society (human reality) (Shaygan and Rahmani Klakuob, 2019). As it can be seen criminal law today is far removed from criminal law in the past. According to the time and place requirements in the broadest sense, the abstract legal view based on a rationality and materials based on science and experience is doomed to regress so that legislators, adopting a realistic criminal policy in the broadest sense, can legislate in Criminal matters according to the time and place requirements an active dynamic state.

\section{a. Crime, a human reality with biological dimensions}

Criminal biology examines the physiological and biological factors of crime and, like criminal psychologist, is considered as one of the factors of realism, including science and knowledge in the service of criminal law. For the first time, Cesar Lembroso, an Italian military physician, established the science of criminal anthropology with the publication of a book entitled The Criminal Man and through introducing the story of congenital or instinctive killer or the principal of criminal inheritance, which aimed to study the physical condition of people with criminal behavior.

The scientific results of his knowledge, especially the role of chromosomal disorders in the individual's attraction to criminal behaviors, and in some people's belief, to the criminal relationship between individual's behavior and parents' behavior, can put the panel system in a different direction. The effect of intellectual transformation on modern positivists, who by transitioning from biological determination to bio-educational the determinism, have believed in a kind of dual physical and social criminal determinism, cannot be ignored in how to attribute criminal responsibility to perpetrators with effective biological and social problems. For this reason, in most penal systems, recognizing the offender's individual and family personality is effective in determining his criminal fate (Faqir, 2016).

Inheritance means conditions that cause the transfer of physical and behavioral characteristics from parents to children (Loeber, et al., 2009). Genetics is the science of transmitting biological information from one cell to another from parent to Infant, and then from one generation to the next. A phenotype is the sum of the physical traits of a living being. This word is opposite to the word genotype which means a set of genetic information of 
a person. Genotype effects genotype for but it can be more or less effective under the influence of the environment. Previously, phenotype meant only traits that could be observed directly, but today it also includes biochemical traits such as the ability or inability to produce a particular enzyme, as well as behavioral traits (Beaver, 2015). Recent research suggests that there are between 20000 to 30000 human genes that scientists have sorted. Organizing the human genome is a first step in understanding exactly how genes is relating to human evolution and the normal function of his life.

For example, much of each gene's function and how different genetic variables are translated into phenotypic variables remains unknown. But regarding these ambiguities, there have been very good studies that link a specific gene to a wide range of disorders, such as ADHD, Attention Deficit Hyperactivity Disorder, alcoholism, and even anorexia or polyphasia, though perhaps the most interesting genetic finding are the results of the small number of the studies that have identify certain genes that are associated with delinquency, aggression and serious violence (Walsh and Beaver, 2009).

What is certain is that genus are more determinants than a complete factor in the occurrence of behaviors. No one is programmed to commit a specific behavior as a robot under the influence of genes. For example, a gene can have the potential for several different behaviors and change a person's function depending on the environment. Also, a gene can be turned off for the rest of a person's life, unless the conditions are right for it to be turned on. In fact, the environment and genes interact with each other, and the lack of one hinders the growth of living things. Undoubtedly, if human knowledge is fully able to surround and control genetics, it will have many positive effects on crime control and treatment. Control of genes after accurate, comprehensive knowledge of their functions can be an effective infallible factor in medical prevention.

Diagnosis of biological diseases affecting delinquency and inclusion of cases in the delinquent personality profile helps the criminal court judge in determining the type and amount of punishments needed for correction rehabilitation and social reintegration, and on the other hand, additional punishments with the nature of security and educational measures that can include a wide range of measures, including medical treatment, can be used and exploited. Since in many cases that offender needs a medical diagnosis and treatment rather than punishment, which the inclusion of criminal biological facts in a realistic criminal policy that leads to the formulation and adoption of dimensional scientific laws in considered a symbol of effective scientific rationality in how to deal with the criminal phenomenon. 

284
Ahmad Reza Vanaki, Karim Salehi y Maryam Naghdi Dourabati
Background of Achieving a Realistic Legislative Criminal Policy in Iranian Penal Laws

\section{b. Crime human reality with psychological dimensions}

Criminal psychology is "studying and researching the psychological cases and nature of crime, as well as paying attention to the personality of the offender and studying the feelings, motives, as well as specific mental states that cause crime" (Thorburn, 2011: 30). The role of psychologists in explaining the phenomenon of crime has been highlighted and since they considered criminals not only from a judicial point of view but also from the point of view of human facts, and instead of judging crime as a separate act they examined personality dimensions. And they accepted that a complete examination of a human being, criminal or non-criminal is possible only by and in-depth examination of his personality. Regarding the application of the principle of individualization of punishments and more than the application of the principle in the judicial stage, which dates back to the time of the adoption of criminal policy, in the justice system as a goal that manifests itself in the legislative state in one dimension depends on applying criminal psychology to help the justice system in solving individual problems by targeting the individual and his direct role (Shaygan and Rahmani Klakuob, 2019).

Criminal psychology is one of the specialized of psychology and is considered a basic branch of criminology. The important missions of this science or recognizing the character of the criminal, recognizing the character the criminal, recognizing the tendencies of anti-social behavior in human beings and evaluating the institutional and acquired factors of such a tendency and its evolutionary course from potential to action, evaluating the level off responsibilities and self-awareness in crime and the role of unconsciousness in absense or decline of criminal responsibility, the treatment of the offender and his social adjustment and elimination of the danger of dangerous criminals and establishment of detention centers and offender, rehabilitation and mental improvement organization, developing and criminal health plan, developing insight and strengthening the sense of recognition and understanding of those in charge of criminal affairs (Cohen et al., 1989).

Realism in the psychological dimension of the criminal phenomenon leads to research on how criminals' personality dimensions are formed and the search for the causes and factors leading to the emergence and prevention of crime and the correction of criminals. One of the criminal psychologies is data that plays an important role in adopting realistic criminal policy to predict legal mechanism under the influence of "legal psychology". Laws that make it possible to assess a defendant in terms of mental is status to determine a person's mental health and insanity at the time of committing the crime. Also, legal psychologists predict and suggest treatment methods for the offender in order to minimize the risk of crimes, especially violent crimes (Ristroph, 2020). 
As we look at Iran's laws, the issue of criminal psychology in the two subissues of personality profile and the criminal development of the subject of Article 91 of the Islamic Penal Code can be considered prominently. The legal provisions in the most sever punishments has offered new balanced solutions based on criminal psychology in Iranian criminal law (Nayyeri, 2012). Legal provisions in the most severe punishments have provided new balanced solutions based on criminal psychology in Iranian criminal law. Although the legislative approach in this realism and relatively rudimentary, and without precise mechanisms and the use of full-time empirical experts alongside the courts, it is a good opening in the realism of Iran's legislative criminal policy.

\section{c. Crime a social reality with a subset of cultural economic environment}

In a division, social environments are divided into cultural environment and economic environment; In Durkheim anomie, part of the criminal phenomenon is formed is due to the unfair division of culture, which of course has a significant and relationship with growth at the social level, and the lack of fair distribution of labor and wealth and economic factors is one of the main causes of crime; And both factors among the fundamental factors of significant to delinquency in a realistic criminal policy in the science of criminal policy and especially in Iranian criminal law. Today, most of the micro-economy crimes in Iran that have financial of financially related roots can be considered related to economics issues.

Crimes such as theft, malversation, unpaid checks, forging, drug dealing, etc. On the other hand, many macroeconomy crimes, sexual crimes, murder, and assault, etc., are closely related to the issue of culture and culture development. In this part of the research, we will examine the facts that govern cultural economic environments and their impact on criminal policy.

\section{d. Crime, is social reality with a cultural subset}

In every society and in its cultural context, there are norms, rules, and values within which the people of that society mainly act and behave.

The legal system of any social or originates from its culture and basically culture should be considered as the soul and body of the criminal policy of that society (Garland, 2006). Suppose the laws of society are in conflict with the cultural values of its members. In that case, the issue of cultural conflict arises, which in itself leads to the confrontation of laws that become abandoned laws due to the lack of social origins.

Torsten Celine believes that cultural conflict represents a conflict between moral values and contrasting behavioral norms, or a lack of belief in 
their conformity. The meaning of behavior criterion is a clear or sometimes implicit rule that a person follows situations where an action or response in necessary on his part (Vito and Maahs, 2015). The main assumption was that: penal law is an interpretation of the laws of culture that govern society. The very complex issue is that most people belong to many social groups, i.e. family, peer groups, and occupational and religious groups are very numerous. When a person lives in an environment where he or she sees somewhat with different rules, he or she should also expect to meet conflicting standards. According to Celine, cultural confrontation occurs when the laws codified in the panel code conflict with a particular group's behavioral criteria (Ristroph, 2020). Value and cultural conflict have been well invisible in Iranian society and law at time; For example, we can refer to the issue of laws regarding hijab and citizens' resistance in this regard, which in many cases there is no conformity in the culture of citizenship and the statute rules, and it has caused many problems in recent years.

The issue of growth is accompanied by a fair division of culture, which in long run brings with it term such as humanity, fairness, self-purification, shrewdness, and liberalism, to set the social free from embezzlement, economic corruption, bribery, and power abuse and so on. Although the issue of culture is associated with some violent street crimes, it can also be addressed in the case of white-collar crime potentials, which happened to be fully compatible with the surrounding Society despite the very high risk, an issue that has its roots in the lack of a growth-oriented and growthcentered program for decades.

Imam Ali (AS) has made to pleasant, thoughtful and wise word in this regard that are remarkable and thought provoking.

First: Mislaan lamp calling for reform.

The role of community officials is also very effective in eliminating the culture of delinquency.

Second: People with their leaders are more like their parents.

People are more like their rules than their fathers in morals and social traits.

Creating a culture is a spiritual environment free from illegitimate violence and crime and fighting those who commit crime is one of the Islamic government's primary duties (Zaffaroni and Oliveira, 2013).

In the words of Imam Ali (AS), one of the rules of the theory of imitation of Tord, which is the learning of the superiors' inferiors, can be clearly seen. People believe in the religion of their rules and learn the culture of altruism, patriotism, self-sacrifice and the key concepts of culture in a practical way from the great people of society overtime. On the other hand, when ordinary people observe that certain individuals easily ridicule law, justice, 
and moral principles, their belief in the mentioned cultural principles disappears. They see the law as a haven for influential people and those in power. When people's belief in the principles and foundations of culture, justice, and law is destroyed and the collective is conscience and social piety necessary for life is declined, ordinary people also consider themselves entitled to commit oppression and crime.

\section{e. Crime, a social reality with and economic subset}

The economic environment plays a special role in the development of the criminal phenomenon. Changing the economic situation from one country to another or in the domestic territory of the country will have a very clear effect on the amount and various forms of crime creating new needs, in particular, will cause suffering for classes whose new development is not in accordance with the statues (Darabi, 2018).

Economic environments are considered as important factors in delinquency and this issue has been considered differently in opinions of various scientists. Among the theories of criminology, Emile Durkheim, Merton, and Cohen's theory of pressure have dealt with societies' realities struggling with economic problems arising from lack of fair distribution of labor and wealth. The theory of pressure is because people in a society have goals to achieve a happy prosperous life, and to achieve their goals, they first of all the resort to legal means.

Failure to do so ultimately leads to the pursuit of illegal means by a person who seeks to achieve their aspirations and even the minimum subsistence needs. Durkheim refers to an economic society and considers the lack of fair distribution of labor and wealth to cause anomie in a society. In fact, anomie is the state of a society in which the division of labor and wealth is disrupted in terms of the disappearance of collective conscience and the feedback of mismanagement of financial resources has not only plunged public culture and economy into the collapse but has pushed society to the point of disintegration (Tavajjohi, 2019).

The principle of individualization of punishments, labelling theory, and the restorative justice are among the criminological data that broadly cover a range of laws in order to enforce realistic criminal policy. Using theories and related data in the legislative issues, the legislator has tried to design laws that consider the personality dimensions of the offender and estimate how dangerous he is and make the best way to deal with this person available to the judicial authority. In fact by recognizing the dimensions of the offender's personality and considering the benefits related to the victim, in this approach, not only the social security of the local community but also the offender's attempted to control himself and compensate the material $\&$ and moral damage of the victim has been considered in many cases. 
However, due to the need to react against delinquency, punishment has also been considered for correctional, educational, and social reintegration purpose.

\section{The principal of individualization}

The principle of individualization of punishments stems from criminal law's evolution towards paying attention to the perpetrator and his personality. Observance of the principle of proportionality of the Crime with punishment in personally provide only one of the purposes of punishment, which guarantees that the offenders deserve to be punished for their act (-Winick and Wexler, 2006). Punishment can play an important role in ensuring that a person is fully entitled to punishment and other utilitarian purposes. In this sense, individualization of punishment is the correction of punishment based on the offender's statues as an individual. In short, the individualization of punishments means that while observing the principle of legality and personal nature of punishment, the judge can impose different punishments for multiple offenders who have committed a single crime by observing the offender's social, physical \& psychological circumstances (Canter, 2008).

Existence of minimum and maximum punishments, rules for amnesty, parole, mitigation and conversation of punishments, rules related to intensification of punishments are examples of the principle of individualization of punishments (Okon, 2014).

Success in applying the principle of individualization depends on accurate and wise estimation of the degree of criminal capability and the state of being dangerous. A state of being dangerous is a condition in which a person has the ability to commit a crime. Clinical criminology seeks to correct treat and prevent recurrence of a crime by multilateral examination of the offender as a physician. Dublino considers the dangerous state to be the potentially exciting and specially the obvious state of one who is actualized at the same time as the difficult social situation (Cohen et al., 1989). From the positivists' point of view, the dangerous situation is the pillar of criminal responsibility or, in their words, social responsibility. Dangerous state replaces fault in classical system or unscientific criminology. Therefore, the dangerous condition of the person should be recognized, and he should be subjected to social measures, and by adopting appropriate measures, he should be corrected and treated so that he can return to society. Contrary to classical criminology, it also includes lunatics and children. Therefore, the crime and its severity are not a criterion for determining punishment, but the degree of the dangerousness of the offender is a measure of punishment and the offender and his criminal capacity should be considered; this view 
has opened new horizons in criminal law (Delshad and Mazaheri, 2018).

The openings are a large part of our criminal law and one of the foundations of realistic criminal policy. Paying attention to the dimensions of personality in order to find out the degree of danger in each of the isolation cases considered by the legislator depends on scientific the specialized the research in biogenic psychogenic and sociogenic dimensions of the offender; therefore, the criminal court judge in this process should be a person specializing in related to sciences or the consulting body, together with the criminal courts, should from a case called the personality profile under the supervision of experienced and skilled experts. However, another effective component in the success of the principle of individualism depends on his specialized research on the dimensions of a person's personality, which experts do.

\subsection{Personality profile, an important means of achieving realism Creating a personality profile to personalize the punishment and enforcing it to correct and treat offenders has long been considered}

In his profile, first of all, the physical biological bodily structure of the offenders, how the brain and endocrine glands work and his disease should be reflected; secondly, his psychological characteristics as well as his psychological reactions must be precisely determined; tiredly, his personal, social, cultural and educational situation, his background and his relation with relatives, etc. Should be determined (Jacobs, 1980: 21).

Thus, given that in criminology, etiology, crime, the effects of various social and individual factors include biological and physiological factors, in the individual's personality profile, all these factors that have led the perpetrator to commit the crime, should also be considered. Since this case is a is specialized support for the judicial authority to correctly diagnose the deterioration of the dangerous situation and criminal potential. Whether the offender needs medical treatment, or the maintenance and implementation of correctional programs depends on the personality profile's scientific professional formation.

In the criminal system of many countries today the examination of the offender's personality is an important factor in judicial decisions, and it can be said that the personality profile is the most important evidence that can change the procedure after criminal system from "establishing a balance between crime and punishment to "provide a treatment proportionate to the crime". In the next stage, after the conviction and sentence execution, the personality profile is used to apply the principle of individualization of the punishments and also to determine and their correctional, educational and treatment methods appropriate to the offender's personality; However, the use of personality profile is not limited to individualization of punishment, 
but the content of this profile is useful and effective for applying many laws and implementing the institutions provided in them (Pinizzotto and Finkel, 1990).

According to article 203 of the Code of Criminal Procedure (Bennett, 1996: 18):

In crimes for which the legal punishment is the deviation of life, amputation, life imprisonment or ta'zir of the fourth degree and above, as well as in intentional crimes against physical integrity for which the amount of blood Money is one third of the full atonement of the innocent or more, the investigator is obliged to issue an order to file a profile for the defendant do the social work unit during the investigation.

This case, which is separate from the criminal case file, contains the following:

A. Report of the social worker regarding the financial, family, and social situation of the defendant.

B. Medical and psychiatric Report.

Also according to clause $\mathrm{C}$ of the article 279 of the Code of Criminal procedure (Bennett, 1996), summary of the defendant's personality profile or mental condition is one of the items that must be mentioned in the indictment.

While the vast majority of the means of judicial individualization provided by the legislature cover great 5 to 8 , therefore, a flaw in criminal policy is evident and their required facts have not been taken into account.

Nonetheless, it is practically impossible to make a scientific decision about the principle of individualization due to the lack of anticipation of the task to form personality profile.

As described above, the most important part of the criminal prosecution process is the preliminary investigation. Considering the criminological data, the necessity of forming a personality profile to use discriminatory means in case if we have considered realistic criminal policy in the broad sense, would be inevitable; however, the lack of anticipation of a task for investigative authorities to make personality profiles for low-level crimes has blocked the way to this criminal policy from the beginning. This is one of the reasons for the meaning of the use of means and in many cases the abandonment of relevant materials. 


\section{The need to establish care office}

Examination of the means of judicial individualization in criminal law, such as suspension of prosecution, postponement of sentencing, semiliberal system and suspension of punishment execution, always reminds us that although according to the data of these criminal law establishments there are effort to avoid imposing punishments for those who deserve them, but caution should be exercised in any case, and offenders should be constantly monitored and given psychological, medical, and his sociological counseling. Undoubtedly, leaving the issue of care to the execution of sentences and officers is doomed to failure from the beginning due to you to their workload; Inevitably, a separate department called the care office albeit under the supervision of the prosecutor's office, is needed to achieve the goals of realistic law, with the recruitment of specialist specializing in criminal psychology, criminal psychology, criminal law, and care forces.

The probation office in France works to carry out a probationary period under the supervision of a judge with a special care officer and supervise that proper execution of the probation period's orders.

At present, the institutions of the principle of individualization, which are considered as one of the most important manifestations of a realistic criminal policy in the broadest sense, in the vast majority of cases require the implementation of special instructions, the correct implementation of which depends on the presence of the Department of Care and the presence of expert. With the legislative vacancy and the unpredictability of such an institution, the grand for achieving the goals of criminal policy in the broad sense in practically unattainable, and this has led to minimizing the citation of legal materials originating from a realistic point of view on the criminal phenomenon. In addition, in some cases, the relevant materials appear in the form of paper and abandoned rules.

The principle of minimum criminal law is one of the causes of the emergence of criminal in inflation and criminal traffic in courts, which itself causes brief unscientific treatment of the criminal phenomenon is noncompliance with the principle of minimum criminal law.

Unregulated criminalization and the influence of criminal law on issues that can be controlled and managed by guaranteeing non-criminal executions or among the factors that waste enough time for scientific and professional investigation of real crimes.

Hence, the minimum principle of criminal law is the norm and regulator of criminal law and criminal interventions; criminal science intervention, as the most intense from of exercising official governmental power, always tends to conquer new territories and develop more than ever. 
Ahmad Reza Vanaki, Karim Salehi y Maryam Naghdi Dourabati
292 Background of Achieving a Realistic Legislative Criminal Policy in Iranian Penal Laws

According to this principle, criminal moderation replaces criminal extremism, and as the results, not only will the ground for the abuse of criminal law, its concepts means and institutions be reduced but also the moderation of the use of idealistic concepts to achieve realism (Ashworth and Horder, 2013).

\section{Conclusion}

Although Iran's legislative criminal policy has not followed a single policy and can be considered in two dimensions, the broad concept and the narrow concept, but the subject of this article, as we have seen, was to examine the areas in which realistic laws in practice are successful, and in the absence of them, not only will they not be considered an opportunity to create security and comfort for the citizens, but they will themselves be the source of much harm in this regard. The realistic criminal policy is the crime policy in the general sense that covers and considers from pre-criminal to post-criminal situations to manage the criminal phenomenon.

One of the factors for the success of a realistic criminal policy lies in this policy's success and approach to crime prevention issues. The reality, in which success brings the formation of a criminal phenomenon to the minimum possible in society at the lowest cost, and neglecting it causes criminal inflation in society. In the meantime, although state-of-the-art prevention creates obstacles to committing a crime, what reduces criminal capacities and dangerous situations lies in growth-oriented prevention. Lack of prevention that can be designed and implemented in the shortterm, mid-term, and long-term and intergenerational period, confront the society with a kind of cultural anomie and the success in designing and implementing the community in terms of life skills.

Undoubtedly, in such a society, legislation based on a realistic criminal policy that believes in human dignity, personality, and punishment in the form of a citizen's right to a criminal will be effective and fruitful. Because only in a society where the division of labor, wealth and culture is done fairly can we face minimal lawlessness and close enough opportunity for realism in criminal law and hope for its effectiveness. Another part of the background of realistic criminal policy should be sought in the ability to identify the occurrence of the criminal phenomenon and, better yet, in how the criminal character is formed. An issue that depends on accurate knowledge of personality dimension in the biogenic, psychologic and sociogenic sectors, and the achievement of which owes itself to the necessity of making a personality profile for crimes in which examples of realism are to be applied; Otherwise, without the need to make a personality profile, not only will s correct estimate of the dangerous is state and criminal potential 
not be obtained, but the citation of realistic material will also be harmful.

As it turned out, realistic laws in the field of enforcement require a department called the probation or care office to be successful, which guarantees the acquisition of the goals of realism in order to achieve reform and self-control with a sufficient number of specialists in the field of forensic medicine, criminal psychology, criminal psychology and personal care forces. And by not anticipate such an institution, not only will the citation of realistic laws remain at a minimum, but if it in is invoked in the field of implementation, it will face a serious problem in achieving its goals, The two factors of crime prevention and observance of the principle of minimum criminal law also remind the background factors, the observance of which is an effective factor to achieve realism and reduce the costs of providing criminal justice in one sector and spending in the right place.

\section{Bibliographic References}

ASHWORTH, Andrew; HORDER, Jeremy. 2013. Principles of criminal law. Oxford University Press. Oxford, USA.

BEAVER, Kevin M. 2015. Genetics and crime. The Encyclopedia of Crime and Punishment. Available online. In: https://onlinelibrary.wiley.com/ doi/epdf/10.1002/9781118519639.wbecpxO73. Consultation date: $12 / 10 / 2020$.

BENNETT, Dale E. 1996. «The 1966 Code of Criminal Procedure» In: La. L. Rev. No. 27, pp. 175.

BRANNIGAN, Augustine. 2013. Beyond the banality of evil: Criminology and genocide. Oxford University Press. Oxford, UK.

BROWN, Darryl K. 2004. Cost-benefit analysis in criminal law. Calif. L. Rev. University of California, Berkeley, School of Law. Vol. 5, No. 92, pp. 323.

CANTER, David D. 2008. Criminal psychology. Hodder Education Group. London, United Kingdom.

CLARKE, Ronald V. 1983. "Situational crime prevention: Its theoretical basis and practical scope" In: Crime and justice. No. 4, pp. 225-256.

COHEN, Morris L; BERRING, Robert C; OLSON, Kent C. 1989. How to find the law. St. Paul, MN: West. Michigan, USA.

CRAWFORD, Adam; EVANS, Karen. 2017. Crime prevention and community safety. Available online. In: https://core.ac.uk/download/pdf/74235992. pdf. Consultation date: 12/10/2020. 
Ahmad Reza Vanaki, Karim Salehi y Maryam Naghdi Dourabati
294 Background of Achieving a Realistic Legislative Criminal Policy in Iranian Penal Laws

DARABI, Shahrdad. 2018. "Evolutions of Crime Prevention Strategy in Democratic Model of Criminal Policy" In: Judicial Law Views Quarterly. Vol. 23, No. 83, pp. 55-73.

DELSHAD, Maryam; MAZAHERI, Amir Masoud. 2018. "Criminal liability of managers and employees of gas companies in light of judicial process" In: Journal of Social Sciences and Humanities Research. Vol. 6, No. 03, pp.23-45.

FARRINGTON, David P. 1995. "The development of offending and antisocial behaviour from childhood: Key findings from the Cambridge Study in Delinquent Development" In: Journal of Child psychology and psychiatry. Vol. 6, No. 36, pp. 929-964.

FAQIR, Raed SA. 2016. "The Criminal Liability of Parent Corporations for Acts of Its Subsidiaries under Criminal Law in Jordan: A Comparative Study” In: Beijing L. Rev. No. 7, pp. 212-231.

GARCIA-YI, Jaqueline. 2014. "Organic coffee certification in Peru as an alternative development-oriented drug control policy” In: International Journal of Development Issues. Vol. 13, No. 1, pp. $72-92$.

GARLAND, David. 2006. “Concepts of culture in the sociology of punishment" In: Theoretical criminology. Vol. 10, No. 4, pp. 419-447.

HOMEL, Ross; FREIBERG, Kate; BRANCH, Sara. 2015. "CREATE-ing capacity to take developmental crime prevention to scale: A community-based approach within a national framework" In: Australian \& New Zealand Journal of Criminology. Vol. 3, No. 48, pp. 367-385.

JACOBS, James B. 1980. "The prisoners' rights movement and its impacts, 1960-80" In: Crime and Justice. No. 2, pp. 429-470.

LOEBER, Rolf; BURKE, Jeffrey D; PARDINI, Dustin A. 2009. "Development and etiology of disruptive and delinquent behavior" In: Annual Review of Clinical Psychology. No. 5, pp. 291-310.

NAYYERI, Mohammad Hossein. 2012. «New Islamic penal code of the Islamic republic of Iran: an overview.» Research Paper Series.

OKON, Etim E. 2014. "Hudud punishments in Islamic criminal law" In: European Scientific Journal. Vol. 10, No. 14, pp.23-42.

PINIZZOTTO, Anthony; FINKEL, Norman. 1990. "Criminal personality profiling” In: Law and Human Behavior. Vol. 3, No. 14, pp. 215-233. 
RISTROPH, Alice. 2020. Criminal law as public ordering. University of Toronto Law Journal. Vol. 70, (supplement 1), pp. 64-83.

STUART, Ross; POLK, Ken. 2017. Violent Crime. In The Palgrave Handbook of Australian and New Zealand Criminology, Crime and Justice (pp. 131146). Palgrave Macmillan, Cham. London, UK.

SHAYGAN, Farideh; ESMAEIL, Rahmani Klakuob. 2019. “The Necessity for the Parliament of Islamic Republic of Iran to Align Itself with International Obligations of State in Combating Crimes Related to Drugs and Psychotropic Substances" In: Public Law Researsh. Vol. 20, No. 62, pp. 101-125.

TAVAJJOHI, Abdolali. 2019. "Criminal Background as a Manifestation of the "Dangerous State" and Its Application to Alternatives of Prison Sentences" In: Criminal Law Doctrines. Vol. 16, No. 17, pp. 3-27.

TRAVIS III, Lawrence F. 2011. Introduction to criminal justice. Routledge. USA.

THORBURN, Malcolm. 2011. Criminal law as public law. Oxford University Press. Available online. In. https://papers.ssrn.com/sol3/papers. cfm?abstract_id=1695544. Consultation date: 12/10/2020.

VITO, Gennaro F; MAAHS Jeffrey R. 2015. Criminology. Jones \& Bartlett Publishers. Massachusetts, USA.

VOLD, George Bryan. 1958. Theoretical criminology. Oxford University Press. Oxford, UK.

WALSH, Anthony; BEAVER, Kevin M. 2009. Biosocial criminology. In Handbook on crime and deviance. Springer, New York, USA.

WARF, Barney; GRIMES, John. 1997. "Counterhegemonic discourses and the Internet” In: Geographical Review. Vol. 87, No. 2, pp. 259-274.

WINICK, Bruce J; WEXLER, David B. 2006. «The use of therapeutic jurisprudence in law school clinical education: Transforming the criminal law clinic» In: Clinical L. Rev. No. 13, pp. 594- 605.

ZAFFARONI, Eugenio Raul; OLIVEIRA, Edmundo. 2013. Criminology and criminal policy movements. Rowman \& Littlefield. Maryland, United States. 
Vol. 39 N $^{\circ} 69$

Esta revista fue editada en formato digital y publicada en julio de 2021, por el Fondo Editorial Serbiluz, Universidad del Zulia. Maracaibo-Venezuela 